\title{
Upper Airway Obstruction in a Resource Poor Country: An Etiological Profile and Management Outcome
}

\author{
Onotai Lucky Obukowho ${ }^{1 *}$ and Ureh Oparaodu ${ }^{2}$ \\ ${ }^{1}$ Department of ENT Surgery UPTH, Port Harcourt, Africa \\ ${ }^{2}$ Department of Ear Nose and Throat Surgery, UPTH, Port Harcourt, Africa
}

Submission: March 18, 2016; Published: March 24, 2017

*Corresponding author: Lucky Obukowho Onotai, Department of ENT Surgery, University of Port Harcourt Teaching Hospital (UPTH), Port Harcourt, Rivers State. Nigeria, Email: onotailuckinx@yahoo.co.uk

\begin{abstract}
Background: Upper airway obstruction had been in existence for a long time, it requires urgent and effective management to prevent severe complications and even fatality. This study determined the prevalence of upper airway obstruction as seen in Port Harcourt Nigeria. It also highlighted the etiological factors and management outcome.

Patients and Methods: A retrospective case series of all patients who presented to the department of Ear, Nose and Throat (ENT) surgery of University of Port Harcourt Teaching Hospital (UPTH) and Kinx Medical Consultants hospital in Port Harcourt, Nigeria, with features of upper airway obstruction from January 2000 to December 2016. Patient records were analyzed for demographic data, clinical profile, etiological factors of upper airway obstruction, investigations done and management outcome.

Results: A total of 560 patients were found to have upper airway obstruction within the study period out of 15,280 patients who presented to both hospitals giving us a prevalence of $3.66 \%$. There were 324 males and 236 females with $\mathrm{M}$ : F ratio of $1.4: 1$. The age range was 5 days to 75 years with a mean of $10.64(S D \pm 6.74$ ) years. Age group $0-5$ years accounted for majority $(n=285,50.89 \%)$ of the cases. Foreign bodies in the larynx ranked highest $(\mathrm{n}=188,33.57 \%)$ as an etiological factor. The commonest procedure done to relief upper airway obstruction was tracheostomy $(\mathrm{n}=275,49.11 \%)$ and there were no mortality associated with the methods/procedures employed to relief the obstruction in our series.

Conclusion: Upper airway obstruction still poses a major management challenge in our environment. Impaction of foreign bodies in the larynx ranked highest as etiological factor. Tracheostomy still remains the commonest procedure done to relief upper airway obstruction in our setting. To reduce the morbidity and mortality associated with upper airway obstruction, prompt diagnosis and management of upper airway obstruction should be practiced by all medical personnel. However, public enlightenment campaign should be carried out routinely to help curb the menace posed by most of the identified etiological factors.
\end{abstract}

Keywords: Upper air way obstruction; Tracheostomy; Laryngeal foreign bodies; Severe respiratory distress; Management outcome

\section{Introduction}

The airways are the channels through which atmospheric air is channeled down to the respiratory epithelium of the pulmonary alveoli. The upper airway extends from the nasal passages to the lower end of the cricoid cartilage (subglottis). Upper airway obstruction refers to conditions where the upper airway is obstructed leading to respiratory distress [1]. It may be partial or complete obstruction of the breathing passages to the lungs. When a patient has upper airway obstruction the associated respiratory distress may be sudden, with only a slight cough/choking for a warning. There is often agitation in the early stages. Symptoms and signs vary according to the site of obstruction and whether it is acute or chronic in nature. Common symptoms include nasal blockage, snoring, shortness of breath, coughing, and choking [1,2]. The signs are dependent on the cause and can include stridor, hoarseness, confusion, restlessness, cyanosis, use of accessory muscles, and suprasternal recession $[1,3]$.

The causes of upper airway obstruction can be classified in many ways, including pathological and anatomical. Diagnosis of the cause of the obstruction requires an accurate history and 
examination, including visualization of the upper airway from the nasal vestibules to the subglottic larynx using flexible fiberoptic endoscopy [1,2]. In the acute situation, arterial blood gases may help to quantify the extent of the hypoxia and any associated acid-base imbalance. Radiological investigations, including plain neck/chest X-rays and computerized tomographic scans, can be useful in selected cases [2,3]. Therapeutic options depend on the etiological agent and the acuteness of onset. Treatment of upper airway obstruction due to a foreign body includes the Heimlich maneuver for adults, a series of five abdominal thrusts for children over 1 year of age, and a combination of five back blows with the flat of the hand and five abdominal thrusts with two fingers on the upper abdomen for infants $[1,4]$.

The priority in acute obstruction should always be securing of the airway either medically or surgically followed by treatment of the underlying cause. In chronic cases, the emphasis is more on investigating and treating the underlying cause. Upper airway obstruction is a serious and potentially life threatening condition and as such requires prompt assessment and management $[3,4]$. Tracheostomy is a well known procedure used by most researchers in securing the patient airway when they present with upper airway obstruction. Other methods of airway intervention may include endotracheal intubation, cricothyroidotomy and percutaneous dilatation tracheostomy $[3,5]$. In our setting there is still paucity of information on the prevalence of upper airway obstruction, hence this study was done to determine its prevalence as seen in Port Harcourt Nigeria. It will also highlight the etiological factors and management outcome of patients with upper airway obstruction.

\section{Patients and Methods}

A retrospective case series of all patients, 5 days old to 75 years who presented with upper airway obstruction to the department of Ear, Nose and Throat (ENT) surgery of University of Port Harcourt Teaching Hospital (UPTH) and Kinx Medical Consultants hospital both in Port Harcourt, Nigeria, from January 2000 to December 2016. Patient records were analyzed for demographic data, clinical profile, etiological factors of upper airway obstruction, investigations and management outcome. The data was entered into the version 16 of the Statistical package for social sciences (SPSS16). Simple descriptive statistics in the form of mean, frequency distribution tables and percentages were used to illustrate data.

\section{Results}

A total of 560 patients had upper airway obstruction within the study period out of 15,280 patients who presented to the Ear, Nose and Throat units of both hospitals giving a prevalence of $3.66 \%$. There were 324 males and 236 females with M: F ratio of $1.4: 1$. The age range was 5 days to 75 years with a mean of 10.64 ( $S D \pm 6.74$ ) years. Age group $0-5$ years accounted for majority ( $n=285,50.89 \%)$ of the cases (Table 1). The study revealed a wide range of causes of upper airway obstruction encountered in a developing tropical country and foreign bodies in the larynx ranked highest $(n=188,33.57 \%)$ (Table 2). Majority of the patients did plain radiographs of the chest and lateral soft tissue of the neck as well as post nasal space. The commonest procedure done to relief upper airway obstruction was tracheostomy $(n=275,49.11 \%)$ (Table 3).

Table 1: Age distribution of patients with upper airway obstruction.

\begin{tabular}{|c|c|c|}
\hline Age group (years) & Number & Percentage (\%) \\
\hline $0-5$ & 285 & 50.89 \\
\hline $6-10$ & 80 & 14.29 \\
\hline $11-15$ & 30 & 5.36 \\
\hline $16-20$ & 25 & 4.46 \\
\hline $21-25$ & 18 & 3.21 \\
\hline $26-30$ & 20 & 3.57 \\
\hline $31-35$ & 16 & 2.86 \\
\hline $36-40$ & 34 & 6.07 \\
\hline $41-45$ & 10 & 1.79 \\
\hline $46-50$ & 12 & 2.14 \\
\hline $51-55$ & 8 & 1.43 \\
\hline $56-60$ & 9 & 1.61 \\
\hline $61-65$ & 4 & 0.71 \\
\hline $66-70$ & 5 & 0.89 \\
\hline $71-75$ & 4 & 0.71 \\
\hline T0TAL & 560 & 100.0 \\
\hline & & \\
\hline & & \\
\hline
\end{tabular}

Table 2: Etiological factors of upper airway obstruction.

\begin{tabular}{|c|c|c|}
\hline Aetiological factor & Number & Percentage (\%) \\
\hline Foreign bodies in the larynx & 188 & 33.57 \\
\hline $\begin{array}{l}\text { Foreign bodies impaction in the } \\
\text { esophagus }\end{array}$ & 52 & 9.29 \\
\hline Laryngeal papilloma & 14 & 2.50 \\
\hline $\begin{array}{l}\text { Obstructive tonsils and adenoid } \\
\text { causing obstructive sleep apnoae }\end{array}$ & 120 & 24.43 \\
\hline Blunt laryngeal trauma & 28 & 5.00 \\
\hline Cut throat injuries & 25 & 4.46 \\
\hline Gunshot injuries to the throat & 32 & 5.71 \\
\hline Lanryngeal cancers & 15 & 2.68 \\
\hline Deep neck space infection & 6 & 1.07 \\
\hline Acute epiglotitis & 6 & 1.07 \\
\hline Laryngomalacia & 20 & 3.57 \\
\hline CROUP & 14 & 2.50 \\
\hline Oropharyngeal tumour & 12 & 2.14 \\
\hline Nasopharyngeal tumour & 13 & 2.32 \\
\hline Corrosive esophagitis & 15 & 2.68 \\
\hline Total & 560 & 100 \\
\hline
\end{tabular}




\section{Global Journal of Otolaryngology}

Table 3: Procedures/methods done to relief the upper airway obstruction.

\begin{tabular}{|c|c|c|}
\hline $\begin{array}{c}\text { Procedure/method done to relief } \\
\text { upper airway obstruction }\end{array}$ & Number & Percentage (\%) \\
\hline Tracheostomy & 275 & 49.11 \\
\hline esophagoscopy & 69 & 12.32 \\
\hline Adenotonsillectomy & 85 & 15.19 \\
\hline $\begin{array}{c}\text { Drainage of deep neck space } \\
\text { abscesses }\end{array}$ & 5 & 0.89 \\
\hline $\begin{array}{c}\text { Excision biosy of oropharyngeal } \\
\text { tumours }\end{array}$ & 8 & 1.43 \\
\hline $\begin{array}{c}\text { Examination of the nose/ } \\
\text { nasopharynx + clearance biopsy }\end{array}$ & 12 & 2.14 \\
\hline Conservative medical treatment & 77 & 13.75 \\
\hline Direct laryngosopy + biopsy & 29 & 100 \\
\hline Total & 560 & \\
\hline
\end{tabular}

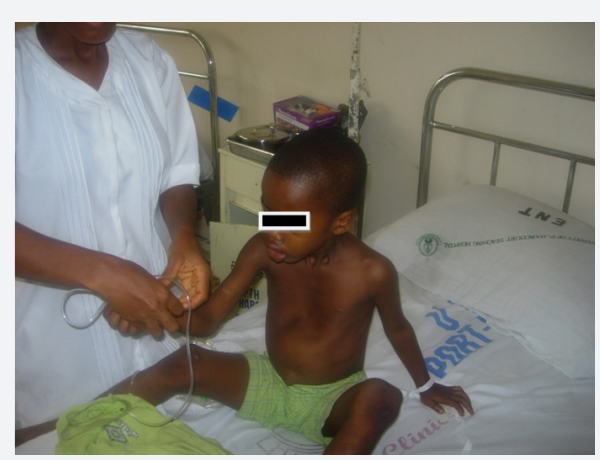

Figure 1: A child in obvious respiratory distress.

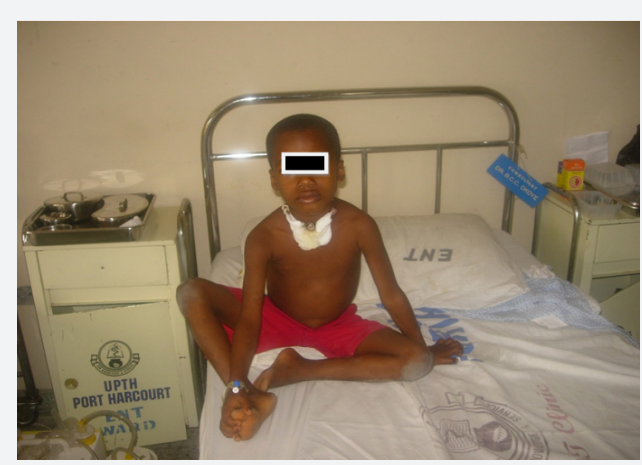

Figure 2: The same child after emergency tracheostomy.

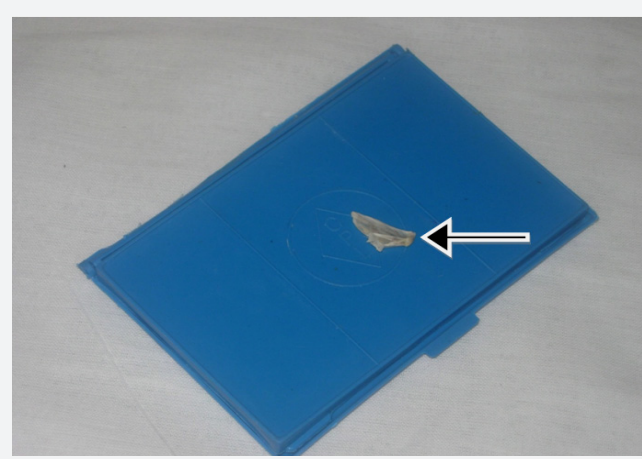

Figure 3: Fish bone removed from the larynx of the child.
Figures 1-3 showed 6 years old boy who had fish bone lodged in his larynx and emergency tracheostomy was done to relief the upper airway obstruction. Figures 4-6 showed the plain radiograph of the lateral soft tissue of the neck of a child that aspirated a metallic spring; he had tracheostomy to relief the airway obstruction before the removal of the foreign body form the larynx. There was no mortality associated with the various methods used to relief the airway obstruction in our series.

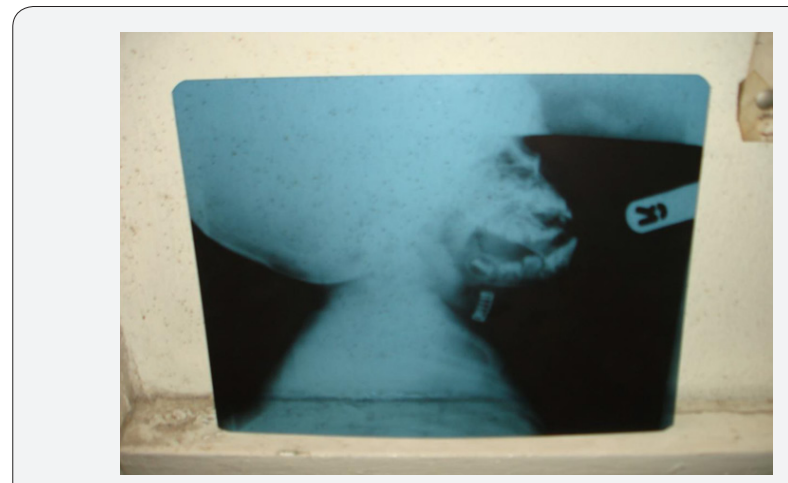

Figure 4: Plain radiograph of the lateral soft tissue neck of a child showing foreign body in the laryngeal airway.

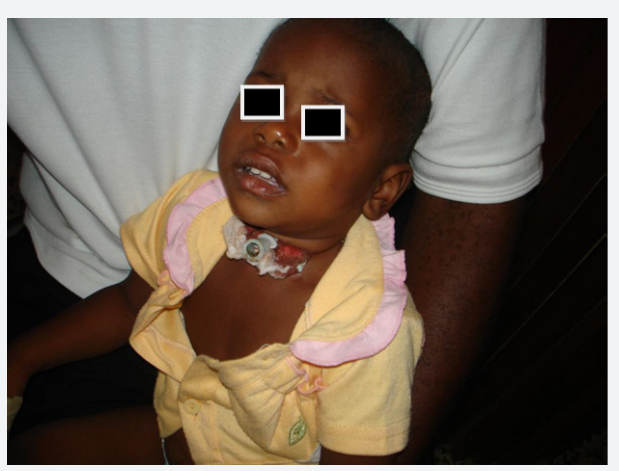

Figure 5: Child who aspirated metallic spring, had emergency tracheostomy to secure the airway before removal of foreign body via direct laryngoscopy.

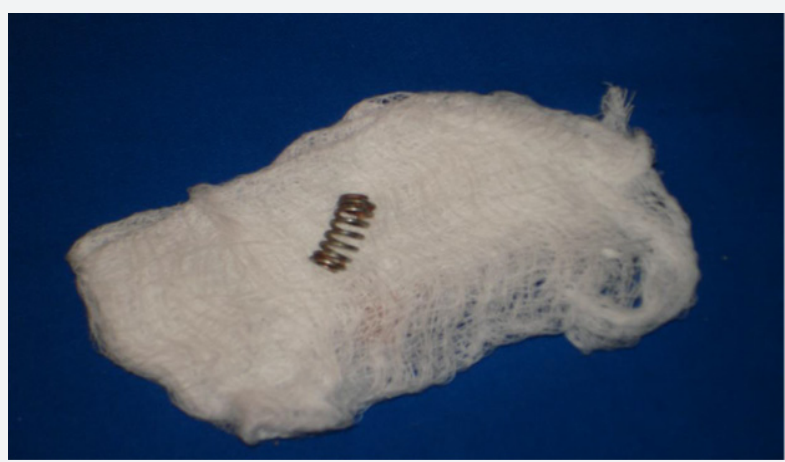

Figure 6: Foreign body (metallic spring) that was removed from the larynx of the child.

\section{Discussion}

Upper airway obstruction in any patient is one of the most challenging acute emergencies which require urgent 
management in order to prevent fatal outcome. The prevalence of upper airway obstruction in our series accounts for $3.66 \%$ of all patients who presented to the ENT units of both hospitals. Chan et al in their work done in 2001 found a prevalence of $3.3 \%$. This finding was slightly lower than ours because in their series they considered only paediatric patients [6]. Be that as it may, upper airway obstruction is a common clinical scenario Worldwide especially in the developing countries $[7,8]$.

In our series we found more male patients who are children presented with upper airway obstruction. This was not a surprise because most documented causes of upper airway obstruction were found more with the male gendre $[2,3,8]$. The study of Dubey and Garap in1999 [9] agrees with our findings. The reason for male predominance in our series could be attributed to the upper airway obstruction due to laryngeal foreign bodies. More male children have been found to have a higher incidence of laryngeal foreign bodies than their female counterparts. Besides, the male children are also more susceptible to foreign body aspiration because of their more inquisitive and exploring nature [8]. Age group 0-5 years accounted for the majority of cases we encountered and this is the age group that is highly predisposed to aspiration and ingestion of foreign bodies $[3,8]$.

The commonest etiological factor that accounted for upper airway obstruction was foreign body impaction in the larynx which agrees with the earlier findings of Dubey and Garap in 1999 and Eziyi et al. [5,9] in 2011 [5,9]. However, this contradicted the findings of Ogunleye et al., in 2001 and that of Adoga and Ma'an in 2010 who found recurrent respiratory pappilloma to be responsible for most of the upper airway obstructions in their series $[2,10]$. Some of the patients who had upper airway obstruction due to obstructive tonsils and adenoid were either managed conservatively with nasal decongestants, antibiotics and vitamin c or had adenotonsillectomy. However, none of them had tracheostomy as part of their management.

In the past, infective conditions such as acute epiglottitis and laryngotracheobronchitis were major etiological factors but the judicious use of antibiotics, endotracheal intubation and conservative management in the paediatric intensive care unit has reduced the incidence of these indications [1016]. Besides, upper airway obstruction from infective process that constituted less than $5 \%$ in this study was more than $1.6 \%$ reported by Adetinuola et al. [18] but was much smaller than $29.5 \%$ previously reported by Amusa et al. $[17,18]$. This finding, therefore, corroborated the report that improvement in healthcare delivery has reversed the previous trend whereby infective process was the major cause of airway obstruction.

Neoplastic conditions were found commoner among the elderly patients while the patients within the middle aged group had more of traumatic injuries such as cut throat, blunt laryngeal trauma and gunshot injuries to the neck $[2,14]$. These findings are similar to the findings that have been documented previously
$[2,5]$. Most patients with laryngeal cancers usually present late with features of acute upper airway obstruction [14]. There are various ways of managing acute airway obstruction. The ability to manage an obstructed airway successfully requires skill and quick thinking. The specific line of management would depend on the cause of the obstruction, the urgency as well as the available facilities at that location. In our series, the majority of the patients' upper airway obstruction was relieved by tracheostomy. This finding agrees with the earlier work done by Okoye [14] in 2000, who reported that majority of his patients had tracheostomies to relief their upper airway obstruction. This could be explained by the fact that majority of our patients presented late with acute upper airway obstruction that needed quick response. Onotai et al. [8] in 2012 reported the same experience.

The methods used to relief the upper airway obstructions in all our patients were satisfactory. Both the surgical procedures and conservative medical management options that were carried out on our patients gave us good clinical outcomes $[19,20]$. The upper airway obstructions were relieved while the definitive management of each case was further carried out to treat the underlying cause of the upper airway obstruction. Our experience in Port Harcourt, Nigeria does not differ from what was obtainable elsewhere especially in our setting $[2,5,12,13]$. However, we are aware of other methods of managing acute upper airway obstruction used by other researchers which includes awake nasal intubation, use of laryngeal mask airway (LMA), cricothyroidotomy, fibreoptic laryngoscopy even though, we did not use some of these methods in our series [19,21-23].

\section{Conclusion}

Upper airway obstruction still poses a major management challenge in our environment. Impaction of foreign bodies in the larynx ranked highest as etiological factor. Tracheostomy still remains the commonest procedure done to relief upper airway obstruction in our setting. To reduce the morbidity and mortality associated with upper airway obstruction, prompt diagnosis and management of upper airway obstruction should be practiced by all medical personnel. However, public enlightenment campaign should be carried out routinely to help curb the menace posed by most of the identified etiological factors.

\section{References}

1. Bradley PJ (1997) Management of obstructed airway and tracheostomy. In: Kerr AG \& Hibbert J (eds). Scott Brown's Otolaryngology. (6 $6^{\text {th }}$ edn), Butterworth-Heinemann, London, UK, 5: 717-718.

2. Ogunleye AO, Nwaorgu OG, Sogebi OA (2001) Upper airway obstruction in Nigeria: an aetiological profile and review of the literature. Trop Doct 31(4): 195-197.

3. Onotai LO, Etawo US (2012) An Audit of Paediatric Tracheostomies in Port Harcourt Nigeria. International Journal of Medicine and Medical Sciences 2(7): 148-153.

4. Linscott MS, Horton WC (1979) Management of upper airway obstruction. Otolaryngol Clin North Am 12(2): 351-373. 
5. Eziyi JA, Amusa YB, Musa IO, Adeniji AO, Olarinoye OT, et al. (2011) Tracheostomy in south western Nigeria: Any change in pattern? J Med Med Sci 2(7): 997-1002.

6. Chan PWK, Goh AYT, Lum LCS (2001) Severe upper airway obstruction in the tropics requiring intensive care. Pediatr Int 43(1): 53-57.

7. Chung-Mo CHOW, Kam-Lau CHEUNG, Kam-Lun HON (2005) Upper airway obstruction in children. Indian J Pediatr 1(2): 5-9.

8. Onotai LO, Ibekwe MU, George IO (2012) Impacted foreign bodies in the larynx of Nigerian children. J Med Sci 3(4): 217-221.

9. Dubey SP, Garap JP (1999) Paediatric tracheostomy: an analysis of 40 cases. J Laryngol Otol 113(7): 645-651.

10. Adoga AA, Ma'an ND (2010) Indications and outcome of pediatric tracheostomy: results from a Nigerian tertiary hospital. BMC Surg 10: 2 .

11. Primuharsa Putra SH, Wong CY, Hazim MY, Megat Shiraz MA, Goh BS (2006) Paediatric tracheostomy in Hospital University Kebangsaan Malaysia - a changing trend. Med J Malaysia 61(2): 209-213.

12. Parilla C, Scarano E, Guidi ML, Galli J, Paludetti G (2007) Current trends in pediatric tracheostomies. Int J Pediatr Otorhinolaryngol 71(10): 1563-1567.

13. Gilyoma JM, Balumuka DD, Chalya PL (2011) Ten-year experiences with Tracheostomy at a University teaching hospital in Northwestern Tanzania: A retrospective review of 214 cases. World J Emerg Surg 6(1): 38.

14. Okoye BCC (2000) Tracheostomy in Port Harcourt. Niger J Surgical Sci 10: $99-102$.
15. Batsakis JG (1979) Squamous cell. 'Papilloma' of the oral cavity, sinonasal tract and larynx. In: Tumours of the Head and Neck Clinical and Pathological Considerations. Williams Wilkins Co, Baltimore, USA, p. 76-85.

16. Nze PU (2006) A five-year review of upper airway obstruction in the immediate general anaesthetic post-operative period in Enugu, Nigeria, 1990-1994. West Afr J Med 25(4): 266-268.

17. Amusa YB, Akinpelu VO, Fadiora SO, Agbakwuru EA (2004) Tracheostomy in surgical practice: Experience in a Nigerian tertiary hospital. West Afr J Med 23(1): 32-34.

18. Adetinuola EJ, Bola AY, Olanrewaju MI, Oyedotun, AA, Alani AS et al. (2011) Tracheostomy in South Western Nigeria: Any change in pattern? Journal of Medicine and Medical Science 2: 997-1002.

19. DeLaurier GA, Hawkins ML, Treat RC, Mansberger AR (1990) Acute airway management. Role of cricothyroidotomy. Am Surg 56(1): 12-15.

20. Geelhoed GC (1996) Sixteen years of croup in a western Australian teaching hospital: effects of routine steroid treatment. Ann Emerg Med 28(6): 621-626.

21. Schwartz DE, Wiener-Kronish JP (1991) Management of the difficult airway. Clin Chest Med 12(3): 483-495.

22. Okafor BC (1981) Tracheostomy: A review. Niger Med J 11: 1-10.

23. Okeowo PA (1983) The role of Tracheostomy in Otolaryngological practice in a developing country. J Otolaryngol 12(4): 231-234.

\section{Your next submission with Juniper Publishers will reach you the below assets}

- Quality Editorial service

- Swift Peer Review

- Reprints availability

- E-prints Service

- Manuscript Podcast for convenient understanding

- Global attainment for your research

- Manuscript accessibility in different formats

( Pdf, E-pub, Full Text, Audio)

- Unceasing customer service

Track the below URL for one-step submission https://juniperpublishers.com/online-submission.php 